\title{
CHALLENGES REFLECTED ON BY STUDENT TEACHERS OF ENGLISH DURING TEACHING PRACTICE
}

\author{
T. W. Molotja* \\ e-mail: wilfred.molotja@ul.ac.za
}

\author{
M. Maruma* \\ e-mail: kgetja.maruma@ul.ac.za
}

*Department of Language Education, Social Sciences

Education and Educational Management

University of Limpopo

Sovenga, South Africa

\section{ABSTRACT}

Teachers are faced with enormous emotional and physical demands on a daily basis; and have little or no time to reflect on their practice. This becomes problematic for student-educators when they are supposed to go through their practice. The dual purpose of this study was, firstly to investigate English language student-educators' challenges experienced during their teaching practice sessions; and secondly: to recommend better strategies through which such challenges could be addressed. The study was informed by Vygotsky's (1978) Social Constructivist theory, which emphasises social learning and interactive teaching. Based on an action research interpretivist's paradigm, using a qualitative approach, 14 semi-structured group interviews were conducted with 100 student-educators purposefully sampled for this study. The participants wrote a once-off reflective essay as part of their practice teaching portfolio. A document analysis approach was applied while reading the essays to identify the teaching challenges. Among others: lesson planning, alignment of teacher's and learners' activities and meaningful content presentations were confirmed to be the most problematic. These findings show a critical need to design strategies to encourage reflective practice in the undergraduate teacher programme.

Keywords: student-educators, reflective practice, teaching challenges, teaching practice

\section{INTRODUCTION}

The teaching of the English Language has been exposed to several challenges and changes in the recent years (Khany and Darabi 2014, 908). The teaching of English language in schools is characterised by a number of curriculum changes which impact on the teachers' practice. These changes are meant to bring about improvements in the teaching profession (Khany and Darabi 2014, 908; Richards and Rodgers 2007, 34). Reflection during and after teaching practice is the pivotal corner stone in teacher training programmes (Farrell 2011,54). The attributes of the $21^{\text {st }}$ 
century educators expect student-educators to reflect on their teaching for improvements on their teaching approach to take place. These national requirements often lead to studenteducators into having some challenges about their reflective approach in the teaching practice. They (student-educators) are supposed to be introduced and mentored in both their professional development as prospective teachers (universities) and in practice (at schools). Nomlomo and Desai $(2014,87)$ encapsulate the importance of reflective teaching by stating that "in every sphere of his/her work, the chartered teacher will be reviewing practice, searching for improvements, turning to reading and search for fresh insights, and relating these to the classroom and the school. He or she will bring to his or her work more sophisticated forms of critical scrutiny, demonstrate a heightened capacity for self-evaluation, and a marked disposition to be innovative and to improve." The above forms part of educator education and our students are expected to reflect on their observations and teaching, as part of their educator development. It is, however, different from the practicum. Students struggle in designing interactive lessons which lead to meaningful learning, hence this study. It therefore, seeks to explore the challenges faced by student-educators when reflecting on their lesson design, alignment of teaching and learning activities and presentations. We also hope that the study will subsequently enable us to design an intervention strategy which will ease the burden of applying reflective teaching in the practice.

\section{DEFINITION OF REFLECTION IN ENGLISH FIRST ADDITIONAL LANGUAGE TEACHING}

El-Dib $(2007,8)$ defines reflection as "the process by which teachers engage in aspects of critical thinking such as careful deliberation and analysis, making choices, and reaching decisions about a course of action related to teaching”. This critical thinking process entails, according to Fat'hi and Behzadpour $(2011,12)$, “identifying questions and key elements of a matter that has emerged as significant, then taking ones' thought into dialogue with oneself and with others". El-Dib $(2007,8)$ again adds that the teacher questions the goals and the values that guide his/her work, the context in which he or she teaches, or his or her assumptions about teaching.

On the other hand, Moon $(2013,1)$ 's definition of reflection focuses on form of the mental processing we use when fulfilling a purpose or achieving some anticipated outcome. We use the mental form to have an insight into complicated or unstructured ideas; and it is largely based on the reprocessing of knowledge, understanding and possibility, emotions that we already possess. Contrary to belief commonly held, Farrell $(2008$; 2013) brings another dimension of reflective practice. He argues that reflective practice in English language teaching occurs when 
"teachers consciously take on the role of reflective practitioner, subject their own beliefs about teaching and learning to critical analysis, take full responsibility for their actions in the classroom, and continue to improve their teaching practice". By engaging in Farrell's description above, teachers thus inculcate the spirit of development and professionalism (Klu et al. 2014, 255) argue that teacher reflection is a part of professionalism because it informs them about the successes of what they are doing and how they go about rectifying their situation. The notion of teacher development is also added by Richards and Rodgers $(2007,8)$, who argue that "in every sphere of his/her work, the chartered educator will be reviewing practice, searching for improvements, turning to reading and research for fresh insights, and relating these to the classroom and the school".

The above annotation clearly indicates that reflection is part of teacher development, and in this case for English language student-educators, it is not an exception. The discussion on reflective thinking is based on Dewey 's theory of reflective teaching as cited in Zeichner and Liston $(2014,14)$. In addition to the springboard of reflection in EFL as the brain product of Dewey's theory, Liou $(2001,255)$ argues that the notion of reflection encompasses emotions, passions, intuitions, and logical thinking. These aspects of reflection are inherent in various types of reflection which an educator may be involved in. An educator may be involved in the reflection in action, on action and after action (Yost, Sentner and Forlenza-Bailey 2000; Ward, McCotter and Suzanne 2004; Farrell and Bennis 2013, 163).

There are different purposes and beliefs about reflection (Farrell 2013, 14; Liou 2001, 197). However, for the purpose of this study, we decided to focus on critical reflection. Liou (2001, 197) again argues that "critical reflection raises teachers' awareness about teaching; enables deeper understanding; and triggers positive change". Students who are involved in critical reflective teaching will be informed of the best or appropriate pedagogic practices and have foundations for development. We believe that $21^{\text {st }}$ century educators should have the intellectual, moral and critical thinking abilities to meet the challenges typically inherent in schools.

In agreement with our belief, the finding in Farrell's (2013) study is that critical reflection forms an integral part of teacher education. In addition to the above, Oder $(2014,482)$ conducted a study on teacher's beliefs about professional teaching. His concern is on the application or alignment between the theory and application in the English language classrooms. It is through the application of the theory that we can make connections between concepts, information and theories. We can also draw theory from practice by developing and understanding the underlying meaning of reflection, in order to better understand the nature of language teaching and learning. Oder further $(2014,482)$ argues "that language learning is not 
necessarily a direct consequence of good teaching, but rather depends on the understanding of different learning styles, motivation, background and purposes of learning, and the understanding that teaching needs to be adapted to students".

\section{CONTEXT AND BACKGROUND}

This study is conducted on the third year student-educators registered at a South African university. Students are registered for the English for Education module which is offered as both a theoretical (content) as well as a method module. As part of the practicum for the theoretical module, students are expected to choose any school at their respective homes (homebased model) where they will be able to go through their practice. It is also worth noting that English is used in almost all the learning areas as the medium of instruction and interaction in South Africa, with the exception of grade $\mathrm{R}$ to grade 5, where it is learned as a subject (Department of Education 2011, 12). The usage of English as a language of learning and teaching gives pressure to the training of educators who are well versed in the teaching methodology and content of this language, hence the imperative of teaching practice module. Teaching practice for the third level students normally takes a period of four weeks during the first semester. The expectation is that students should be mentored into the practicum by their mentor teachers at schools. This necessitates that they prepare lessons based on the major subjects; and present them in their allocated classes. In addition to the above, they should also observe and reflect on the school's culture and its environment as a whole (whole school observation and reflection).

\section{CONCEPTUAL FRAMEWORK}

The practice of reflective teaching in English language teaching is informed by the Social Constructivist theory. The social constructivist theory sees teaching and learning in the social context of constructing knowledge. Vygotsky (1978) puts learning in the centre of the social context. For teaching and learning to take place, teachers must contextualise their practice. Fat'hi and Behzadpour $(2011,12)$ view constructivism as "an active process where learners reflect upon their current and past knowledge and experiences to generate new ideas and concepts". In support of the social constructivist theory in education, Fat'hi and Behzadpour $(2011,12)$ view reflection as an integral part of teacher training and development the $21^{\text {st }}$ century.

\section{THE IMPORTANCE OF REFLECTION IN ENGLISH LANGUAGE TEACHING}

We believe that teacher education training should be aligned with the $21^{\text {st }}$ century conventions 
and the Department of Higher Education's (2017) goals, on initial teacher education. We view and value teaching practice as a platform offered for the production of quality educators who are able to reflect during their practice. We, therefore, agree with El-Dib (2007) that reflection in teaching is seen as an important factor in teacher education. It is through reflection that student teachers will actualise their experience of learning from practice (university theory) into learning in practice (school-based experience) (Yost, Sentner and Forlenza-Bailey 2000, 13). In addition to the above, we also view reflective teaching as benefitting students in reacting, examining and evaluating their teaching to bring about necessary changes; to improve attitudes, beliefs and teaching practices (Fat'hi and Bedzapour 2011, 11; El-Dib 2007, 17; Farrell 2013, 1070). Reflective teaching can help to facilitate the process of gaining better insights into teaching from both a theoretical and a practical perspective. It can also affords students an opportunity for self-appraisal, since it also does more good than harm in professional development. Subsequently, the teachers can become more empowered decision makers, engaging in systematic reflections of their work by thinking, writing, and talking about their teaching, observing the acts of their own and others' teaching: by gauging the impact of their teaching on their students' learning. They naturally locate themselves within their profession and start to take more responsibility for shaping their practice (Fat'hi and Behzadpour 2011, 12; Farrell 2016, 17). The aim of reflection in this case is to bring an alignment of the academic programme with its practical application in an actual classroom through practical experience (Frick, Carl and Beets 2010, 421).

\section{THE AIM OF THE STUDY}

This study aimed at investigating the challenges from students' reflections on the practice teaching of English First Additional language by third year student educators at a South African university. In investigating these challenges, students were requested to respond to the following research questions:

- What are the challenges (positive and negative) facing English FAL student-educators in teaching English during the teaching practice sessions?

- What strategies can be implemented in addressing these challenges?

\section{METHODOLOGY}

In conducting this study, we embarked on an action research where we applied the qualitative methodology in collecting data (Creswell and Clark 2013, 29; Babbie and Mouton 2002, 46; Denscombe 2013, 57). Burns $(2010,18)$ view action research as takins a self-reflective, critical 
and systematic approach to explore one's own teaching context. We believe that in empowering students to reflect in their practice, we will succeed in inculcating the requirements of the $21^{\text {st }}$ century good educator and bring change in the traditional approach (Burns 2010, 18). Again, it is through the qualitative study that the researchers got to understand students' experiences through reflection on their teaching practice. It clearly familiarised the researchers with the situation under which student-educators find themselves dipped in uncomfortable situations when they are sent for practice teaching at their home schools. We also employed document analysis as a data collection instrument in this study.

\section{DATA COLLECTION}

Students enrolled in the School of Education, and registered for English Education were purposefully sampled for this study. Consent forms where distributed to all students sampled for the study. These students are those who have registered for PGCE, Bed SPF at levels 3 and 4 respectively; taking English First Additional Language as one of their major teaching subjects. They were instructed to write essays where they critically reflect on their teaching practice experiences during the first semester teaching practice sessions (Zeichner and Liston 2014, 12). The writing of essays is deemed to be the correct tool because they are described as instruments through which data may be collected by students. Students had to reflect on their application of the methodology learnt during their contact with the methodology lecturers in class. As part of their practice teaching, students were requested to observe lessons taught by their mentor educators, design lessons in teaching English First Additional language skills as contained in their CAPS document. The students involved in the study were from two different provinces in South Africa. In their reflection, students were required to respond to the questions as stated in the section below.

\section{RESULTS}

The following discussion will focus on the challenges experienced by student-educators during their teaching practice sessions.

Table 1: Challenges experienced by student-educators during their practice teaching

\begin{tabular}{|cl|}
\hline \multicolumn{2}{|l|}{ CHALLENGES } \\
\hline 1. & Overcrowding. \\
2. & Weak lesson plans. \\
3. & Teaching approaches, especially the ones applied by PGCE students. \\
4. & Methods of teaching literature PGCE students. \\
5. & Learners' difficulty in speaking through the language of learning and teaching (English). \\
\hline
\end{tabular}




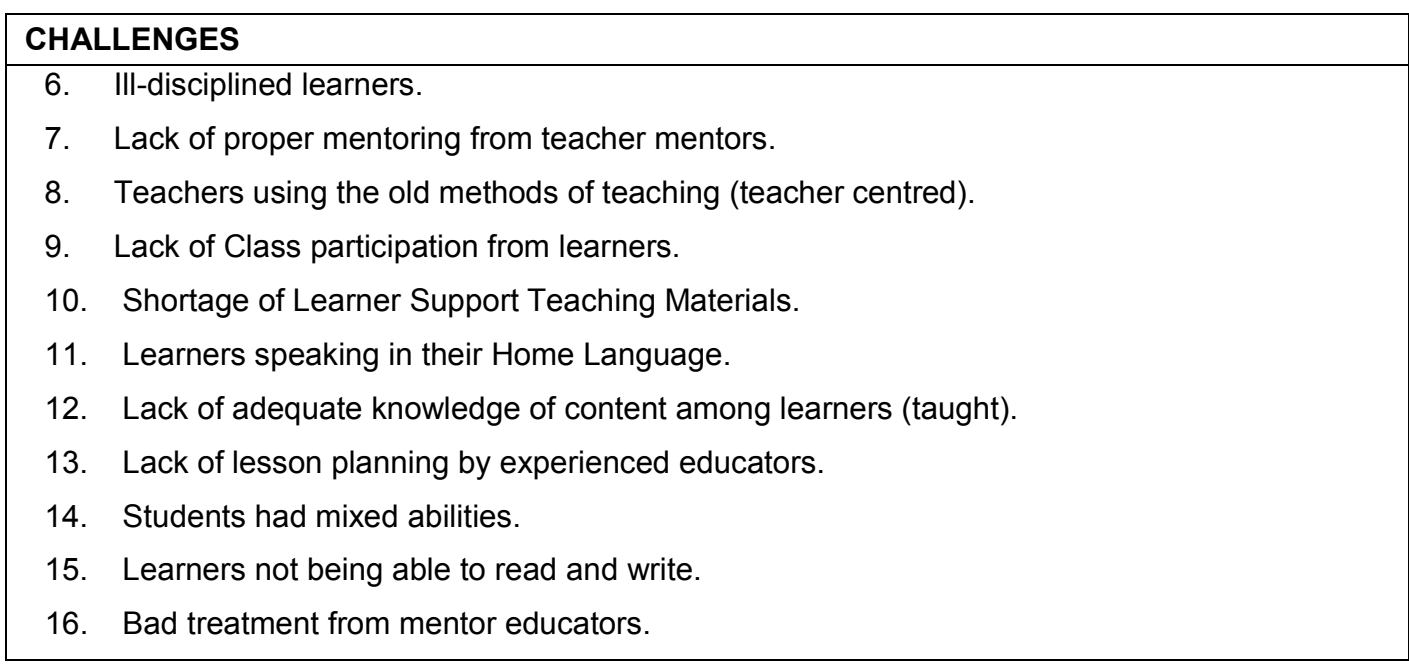

"They did not even bother to guide us as to how teaching should be done. We just observed for a few days and after that they did not even bother to come to class with us to observe if we were applying the correct methods or not. They did not even guide us as to how classwork and tests should be set from student's observation."

"When it comes to the lesson presentation, I had to be the best in everything. I followed my lesson plan as far as my learning objectives, teaching methods and my assessment are concerned. Almost all my lesson presentations were perfect, my mentors can be the witness to this. The learners and I were in another ship heading to promise land. We engaged each other in the activities of the lessons."

Table 2: Positive factors

\section{POSITIVE ASPECTS}

1. Implementing the Communicative Language Teaching method - helped class in learners participating.

2. The application of the bottom up reading strategies.

3. Relating teaching to learners' real-life experiences.

4. The use of group activities as a strategy to engage learners.

5. Had an opportunity to apply most of the methodology learnt at the university - developing effective and engaging teaching strategies in the classroom, creating a safe classroom environment, and discovering individuals' learning styles.

Table 3: Suggested solutions

\section{SOLUTIONS}

1. Teach in a more learner centred way.

2. Be familiar with various teaching methods.

3. Parent involvement.

4. Engage learners in peer feedback where they mark each other's scripts.

5. Students write feedback on each and every lesson attended.

6. More involvement of mentor educators in equipping students with knowledge and skills. 


\section{DISCUSSIONS AND RECOMMENDATIONS}

It is also acknowledged in some cases that there are good mentors who assisted studenteducators in executing their practise teaching successfully. However, a more convenient atmosphere needs to be created for students to be able to teach in a learner centred way. The issue of overcrowding in classrooms lies within the jurisdiction of the government, and as such students may not have alternative solution.

The researchers would like to recommend that a solution be reached with mentor educators at schools to assist student-educators in dealing with the challenges they come across. Proper communication channels with school principals and mentors should be established. And lastly, learners should be encouraged to communicate in the language (English First Additional language) of they are being taught.

\section{REFERENCES}

Babbie, E. and J. Mouton. 2002. The practice of social research. Oxford University Press.

Burns, A. 2010. Doing action research in English Language teaching. Routledge. New York and London.

Creswell, J. and V. P. Clark. 2013. The mixed methods reader. Thousand Oaks, LA: Sage.

Denscombe, M. 2013. The good research guide for small scale social research projects. $4^{\text {th }}$ Edition. McGraw Hill. Open University Press.

Department of Education. 2011. Curriculum and Assessment Policy Statement. Government Printers Pretoria.

Department of Higher Education. 2017. Teaching Practice Round TABLE: Towards the development of a visible Teaching Practice Platform. July 2017. Pretoria.

EL-Dib, M. 2007. Levels of reflection in action research. An overview and an assessment tool. Teaching and Teacher Education 23(1). Di:10,1016/j, tate.2006.04.002.

Fat'hi, J. and F. Behzadpour. 2011. Beyond method: The rise of reflective teaching. International Journal of English Linguistics 1(2): 241-251. http://ezproxy.aus.edu/login?url=http://search. proguest.com/docview/1045851820?accountid=16946

Farrell, S. C. 2008. Reflective language teaching: From research to practice continuum. London. UK.

Farrell, S. C. 2011. Explaining the professional role identities of experienced ESL teachers through reflective practice. System 39: 54-62.

Farrell, S. C. 2013. Reflecting on ESL teacher expertise: A case study. System 41: 1070-1082.

Farrell, S. C. 2016. Surviving the transition shock in the first year of teaching through reflective practice. System 61: 12-19.

Farrell, S. C. and K. Bennis. 2013. Reflecting on ESL teacher beliefs and classroom practices: A case study. RELC Journal 44(2): 163-176.

Frick, L., A. Carl and P. Beets. 2010. Reflection as learning about the self-context: Mentoring as catalyst for reflective development in pre-service teachers. South African Journal of Education 30: 421437.

Khany, R. and R. Darabi. 2014. ELT in Iran: Reflection of the principles-based and post-method pedagogy in language teaching. Procedia-Social \& Behavioural Sciences 98: 908-916.

Klu, E. K., L. M. P. Mulaudzi, N. C. Neeta, W. J. Gudlhuza, R. M. Makhwathane and M. J. Maluleke. 
2014. Towards the professionalism of teaching through improving teacher knowledge and teacher development. International Journal of Educational Science 6(2): 255-262.

Liou, H. C. 2001. Reflective practice in a pre-service teacher education program for high school English teachers in Taiwan, ROC. System 29(2): 197-208.

Moon, J. A. 2013. Reflection in learning and professional development: Theory and Practice. Routledge FALMER. London \& New York.

Nomlomo, V. and Z. Desai. 2014. Reflections on the development of a pre-service language curriculum for the BEd (Foundation Phase). South African Journal of Childhood Education 4(3): 87-102. ISSN: 2223-7674 (C) UJ.

Oder, T. 2014. English language teachers' perceptions of professional teaching. Teacher Development 18(4): 482-494. http://dx.doi.org/10.1080/13664530.2014.953253.

Richards, J. C and C. Lockhart. 2009. Reflective teaching in second language classrooms. Cambridge University Press.

Richards, J. C. and C. Rodgers. 2007. Approaches and method in language teaching. $3^{\text {rd }}$ Edition. Cambridge University Press.

Vygotsky, L. 1978. Interaction between learning and development. In From Mind and Society, 79-91. Cambridge, MA: Harvard University Press.

Ward, R., S. McCotter and S. Suzanne. 2004. Reflection as a Visible Outcome for Preservice Teachers. Teaching and Teacher Education: An International Journal of Research and Studies 20(3): 243257.

Yost, D. A., S. M. Sentner and A. Forelenza-Bailey. 2000. An examination of the construct of critical reflection: Implications for teacher education programing in the $21^{\text {st }}$ Century. Journal of Teacher Education January-February 51(1).

Zeichner, K. M. and D. P. Liston. 2014. Reflective teaching: An introduction. Routledge. New York. 